\title{
The \\ accute \\ effects \\ of \\ resistance \\ exercise \\ on \\ intraocular
}

pressure

Efeitos agudos do exercicio de resistência na pressão intra-ocular

$\begin{array}{lcl}\text { Geraldo } & \text { Magela } & \text { Vieira }^{1} \\ \text { Eduardo } & \text { Pinfieiro } & \text { Penna }^{2} \\ \text { Martin } & \text { Bottaro } & \text { Marques }^{3} \\ \text { Ricardo } & \text { Flávio } & \text { Bezerra }^{4}\end{array}$

Faculdade de Ciências da Saúde da Universidade de Brasília.

${ }^{1}$ Mestre em Oftalmologia, médico do Hospital Universitário de Brasília.

${ }^{2}$ Doutor em Oftalmologia, médico do Hospital Universitário de Brasília.

${ }^{3}$ Phd em fisiologia do exercício, professor do departamento de Educação Física da Universidade Católica de Brasília.

${ }^{4}$ Mestrando em Educação Física pela Universidade Católica de Brasília.

Endereço para correspondência: Geraldo Magela Vieira - SQS 306, B1. G apart. 405 - Brasília (DF) CEP 70353-070

Fone: 55-61-443 3305, Fax: 55-61-443 0814

E-mail:magela@ambr.com.br

Recebido para publicação em 01.03.2002 Aceito para publicação em 11.09.2002

\section{ABS TRACT}

Purpose: To study intraocular pressure (IOP) variations in healthy volunteers after weight lifting, in the supine position. Methods: A descriptive study was designed. Thirty-four individuals were preselected for this study, and a group of 25 volunteers fulfilled the inclusion criteria for joining the initial phase of this research. All of them were healthy without glaucoma. They were asked to lift an $85 \%$ top load in the supine position for 8 times. IOP was measured before and after the exercise. Student's $t$ test was used to analyze the IOP variations. Results: A small, but significant IOP decrease $(1.61 \mathrm{mmHg}$ ) was obtained after exposing 25 individuals (49 eyes) to a specific physical effort. Conclusions: After a session of weight lifting in the supine position with $85 \%$ top load for 8 repetitions, there is a small, but significant IOP decrease.

Keywords: Intraocular pressure/etiology; Weight lifting; Sports

\section{INTRODUCTION}

Several studies have shown the effects of IOP reduction after practicing aerobic and anaerobic physical activities ${ }^{(1-4)}$. The causes of such changes have been the target of many studies. An increase in lactic acid and in plasmatic osmolarity, and also a decrease in blood $\mathrm{pH}$ are considered the main causes of these IOP variations ${ }^{(5-6)}$. Hyperventilation was also pointed out as a cause of IOP decrease after exercising ${ }^{(7)}$.

An increase in IOP after the Valsalva maneuver was demonstrated when this maneuver was employed aiming to simulate weight lifting, but not weight lifting itself ${ }^{(8)}$. Marcus et al. have shown the effect of IOP reduction after isometric muscular contractions, as well as an inverse correlation with lactic acid and $\mathrm{pH}$ serum levels ${ }^{(9)}$. An IOP decrease was also found after physical exercises by employing isometric muscular contractions (in which the size of muscular fiber remains constant, while the tonus and the resistance against which the muscle works increase) and isokinetic muscular contractions (in which the size of the muscular fiber varies during the exercise, while the speed at which the exercise is made remains constant $)^{(1)}$.

Despite the above mentioned studies, there are no reports in the literature - as far as this author knows - on the variations of IOP after weight lifting itself (isotonic muscular work, in which the size of muscular fiber decreases during contraction and the speed of the exercise does not remain constant).

\section{PURPOSE}

To study IOP variations after isotonic exercise of weight lifting in the supine position, in hypertrophy work, by healthy male young individuals. 


\section{PATIENTS}

Thirty-four volunteers were pre-selected for this survey considering the fact of being young soldiers, who had already been submitted to pre-admissional health examinations. All were male soldiers belonging to the staff of the Air Force Hospital in Brasília, in the VI Air Command Region - VI COMAR.

Among them, 25 were selected according to the inclusion and exclusion criteria of this study (as follows).

All participating volunteers were submitted to a questionnaire on systemic and ocular diseases as well on use of systemic and topical medication. None of them answered affirmatively to any alterations that could influence IOP, including regular use of alcohol. The use of illegal drugs was not questioned since the answer in a group of Air Force soldiers could not be trusted.

Later, these volunteers were submitted to a complete eye examination, consisting of extrinsic eye musculature, static refraction with visual acuity, biomicroscopy of the anterior segment, direct monocular fundoscopy and Goldmann's tonometry.

The inclusion criteria of this study were the following: male volunteers from 18 to 30 years old, healthy, irrespective of their athletic fitness and who agreed to sign the informed consent of the procedure.

The exclusion criteria were the following: obesity ${ }^{(10)}$, systemic illness related to glaucoma, use of any topical or systemic medication that might influence IOP in any way, myopia greater than -2.00 , hypermetropy greater than +3.00 , astigmatism greater than 2.00, pigmentary dispersion syndrome (PDS) or pigmentary glaucoma (PG), IOP less than 9.0 or over $22.0 \mathrm{mmHg}$ under applanation tonometry in the sitting position, episcleral venous congestion, or any other eye disease capable to cause glaucoma or to influence IOP or the measurement of IOP by the method of applanation, incapacity to lift weights or not agreeing to sign the informed consent of the procedure.

A small room in the Air Force Hospital was used to perform the measurements. A supine seat was installed. It is a seat that allows a person to lay down on the back with the feet on the floor, and its main edge has two supports to hold the bar with the load to be lifted.

The first step was to calculate the top load that each individual could lift. So, each individual was submitted to a quick session of 3-minute stretching of arm and chest musculature, followed by working out.

Top load is defined as which a person can lift once, not being able to lift it again, even making the greatest effort. Three attempts were made to determine such load, with a fiveminute break after each one. The load used on the first attempt was based on subjective observation of the athletic fitness of the individual or on information provided by him, in case he already practices this sport.

The next step was establishing the kind of work to be practiced. One decided to use in this study the isotonic work, which aims at gaining muscular hypertrophy, and uses $85 \%$ of the top load in eight repetitions (to lift and put down the bar eight times). A break of 24 hours was given between the calculation of the top load and the beginning of IOP measurements.

After the stretching session, the volunteer remained on the supine seat for five minutes. Then, a drop of proxymetacaine hydrochloride was placed in his eye, followed by a stick of $5 \%$ sodium fluorescein moistened with a saline solution in the conjunctival sac. The first measurement was made, first on the right eye and next on the left eye, using Perkins' tonometer (Clement Clark), only by the author of this survey, who has about a two-year experience with this kind of tonometer, which was set according to the rules of the manufacturers manual. All IOP measures were rechecked once in each eye, both before and after the workout.

Measurements were made always in the morning from 10:00 to 12:00, with the room half-illuminated in order to render the reading of the tonometer easier. No pressure was made over the eyelids to keep them open during IOP measuring, and care was taken not to make any pressure over the volunteers' thorax. They were told to look up toward the ceiling.

Results were considered in a 0.5 -millimeter of mercury $(\mathrm{mmHg}) \mathrm{scale}$, with approximation of measurements to .5 or .0, according to the author's reading perception.

A brief simulation of the work was then performed, especially regarding breathing without any load. The volunteer was supposed to expire while lifting the load and to inspire while putting it down.

Then, the exercise itself was started, helping the volunteer to take the load from the support.

After completing eight repetitions, which took around 30 to 40 seconds, $5 \%$ sodium fluorescein was dropped into each eye and IOP was measured again with the same tonometer, and other results were recorded.

It was not possible to make a satisfactory IOP measurement in the left eye of individual XVIII, because he simply couldn't keep his eyes open any longer.

\section{RES ULTS}

Among 34 preselected individuals, 25 met the inclusion and exclusion criteria for this study and were submitted to the test.

The average age of the volunteers was 22.32 years, with a standard deviation of 3.11 years. The youngest individual was 19 and the oldest 30 years old. $92 \%$ of them were aged from 19 to 25 years.

The average load among the volunteers was $56.96 \mathrm{~kg}$, ranging from to $84.0 \mathrm{~kg}$, with a standard deviation of $14.19 \mathrm{~kg}$. The average of $85 \%$ of the top load (which is the load defined to perform the work out) was $48.42 \mathrm{~kg}$, with a standard deviation of $12.06 \mathrm{~kg}$. IOP results before and after exercising are listed in Table1. In some eyes, there was no alteration (LE 


\begin{tabular}{|c|c|c|c|c|c|}
\hline Individual & Age & Top load (kg) & $85 \%$ of Top load $(\mathrm{kg})$ & Inicial IOP (Laid) RE/LE & Final IOP (Laid) RE/LE \\
\hline 1 & 20 & 72 & 61.2 & $24 / 26$ & $22 / 23$ \\
\hline II & 24 & 54 & 45.9 & $14 / 15$ & $12 / 12$ \\
\hline III & 22 & 54 & 45.9 & $18 / 17$ & $14 / 13$ \\
\hline IV & 19 & 68 & 57.8 & $15 / 15$ & $13 / 15$ \\
\hline V & 20 & 68 & 57.8 & $17 / 16$ & $16.5 / 16.5$ \\
\hline VI & 21 & 84 & 71.4 & $12 / 12$ & $10 / 10$ \\
\hline VII & 21 & 76 & 64.6 & $18 / 18$ & $16 / 17$ \\
\hline VIII & 30 & 68 & 57.8 & $18 / 18$ & $17 / 19$ \\
\hline IX & 25 & 80 & 68.0 & $13 / 13$ & $11 / 11$ \\
\hline $\mathrm{x}$ & 23 & 42 & 35.7 & $16 / 15$ & $14 / 15$ \\
\hline$X I$ & 21 & 50 & 42.5 & $12 / 12$ & $10 / 10$ \\
\hline XII & 30 & 50 & 42.5 & $18 / 17$ & $17 / 17$ \\
\hline XIII & 19 & 46 & 39.1 & $15 / 15$ & $11 / 12$ \\
\hline XIV & 21 & 48 & 40.8 & $15 / 15$ & $14 / 14$ \\
\hline$x V$ & 23 & 58 & 49.3 & $13 / 15$ & $12 / 13$ \\
\hline $\mathrm{XVI}$ & 23 & 40 & 34.0 & $22 / 22$ & $28 / 22.5$ \\
\hline XVII & 25 & 32 & 27.2 & $18 / 18$ & $13 / 13$ \\
\hline XVIII & 25 & 76 & 64.6 & $16 /$ & $16 /$ \\
\hline XIX & 19 & 62 & 52.7 & $21 / 16$ & $22 / 21$ \\
\hline$x x$ & 20 & 42 & 35.7 & $20 / 20$ & $14 / 16$ \\
\hline$X X I$ & 19 & 44 & 37.4 & $16 / 17$ & $14 / 14$ \\
\hline XXII & 21 & 56 & 47.6 & $15 / 15$ & $14 / 13$ \\
\hline XXIII & 25 & 64 & 54.4 & $19 / 19$ & $13 / 15$ \\
\hline XXIV & 23 & 50 & 42.5 & $18 / 20$ & $16 / 16$ \\
\hline$X X V$ & 19 & 40 & 30.0 & $18 / 21$ & $16 / 19$ \\
\hline
\end{tabular}

of individuals IV, X and XII and RE of individual XVIII), neither IOP increase (LE of individuals V, VIII, XVI, and XIX and RE of individuals XVI and XIX) after exercising.

In all the other eyes of the individuals submitted to this test (49 eyes of 25 individuals) there was IOP decrease after performing weight lifting, an isotonic physical exercise, according to Table 1.

To analyze the results, Student's $t$ test was applied.

Data were those of the two eyes of 24 volunteers, and only the right eye of individual XVIII was not measured, totalizing 49 eyes, for there were no statistical differences between LE and RE IOP averages both before and after exercising (Table 2).

According to this table, one can see that IOP after exercising was decreased by $1.61 \mathrm{mmHg}$ and this decrease was statistically significant according to the paired $t$ test, as shown in Table 3.

According to Table 3, the difference between the averages is statistically significant, at a level of 0.01 (highly significant).

\begin{tabular}{|c|c|c|c|}
\hline & IOP avarege & Standard deviation & Standard error \\
\hline Before & 16.90 & 3.10 & 0.44 \\
\hline After & 15.29 & 3.82 & 0.55 \\
\hline
\end{tabular}

\section{DISCUSSION}

In this study, a significant decrease of IOP was observed after performing eight repetitions of $85 \%$ top load weight lifting in the supine position by a group of healthy male youngsters.

In some studied eyes there was, however, no IOP alteration or even a small increase. Except for other possible reasons, discussed below, the fact of IOP not undergoing any change or increasing just a bit can be due primarily to the employed measuring method, for, despite the fact that Perkins' manual applanation tonometry is a valuable instrument in clinical and laboratorial IOP measurements, small alterations are inherent in the subjective character of this method ${ }^{(11)}$. In addition, IOP values were shown to vary constantly ${ }^{(12)}$. So, it is hard to obtain two IOP measurements with a high level of reliability. Also, investigations suggest that the second IOP measurement reaches a similar or slightly inferior value than the first if it is repeated immediately ${ }^{(13)}$. In this study, the final IOP value (after exercising) was measured a few seconds after the initial IOP measurement (before exercising). Another limitation of this study regards the kind of bias known as diagnosis suspicion, in which there is a tendency of the person performing the measurements reads not to be impartial, in order to obtain more relevant outcomes. This could be partially avoided by asking a third person to read the measures found, but this did not happen. However, the measurer was aware of this bias. 


\begin{tabular}{|c|c|c|c|c|c|c|c|}
\hline Eye & Average & $\begin{array}{l}\text { Standard } \\
\text { error }\end{array}$ & $\frac{\text { Safety }}{\text { IL }}$ & $\begin{array}{c}\text { break }(95 \%) \\
S L\end{array}$ & $\underset{t}{\text { Statistics }}$ & $\begin{array}{l}\text { Freedom } \\
\text { levels }\end{array}$ & P-value \\
\hline Left-Right & 1.74 & 0.32 & 1.10 & 2.39 & 5.42 & 48 & 0.01 \\
\hline
\end{tabular}

Pigment dispersion syndrome (PDS) or the pigmentary glaucoma (PG) is a cause of IOP increase after basketball matches ${ }^{(14)}$, and the studied exercise may have a potential to cause a release of pigment, which could lead to an IOP elevation that could explain the increase of IOP found in individuals XVI and XIX. Therefore, these individuals were rechecked and considered negative for PDS and PG.

Among the studies trying to correlate weight lifting and IOP, one of the most mentioned in literature is that by Biró and Botar $^{(8)}$. By measuring IOP after 100 and 1000 meter races, where, as in many other studies an IOP increase was obtained, athletes provoked the Valsalva maneuver contracting the abdomen muscles trying to simulate the effort that happens during weight lifting and ring fights. An IOP increase was found using this procedure. Other authors studied IOP variations after the Valsalva maneuver, but the results are contradictory ${ }^{(15-19)}$. However, there is a certain point in relating the Valsalva maneuver to physical activity, and especially concerning weight lifting, one can take for granted that both of them produce the same effects on hemodynamic and biochemical factors, and consequently, on IOP to which such factors would be related.

Another factor that may have influenced IOP and caused its decrease is hyperventilation ${ }^{(7)}$. However, in another study, the same author, in 1994, could not establish a correlation between hyperventilation and IOP decrease ${ }^{(20)}$.

An IOP decrease was demonstrated in a similar study on physical effort during and after handgrip isometric exercise ${ }^{(9)}$. This kind of contraction was not, however, the same as that here studied.

The correlations between IOP and anaerobic effort were also the aim of another study ${ }^{(1)}$. IOP variations in isometric and isokinetic physical activities of normal individuals were compared, and IOP decrease was obtained in both cases, related to the amount of effort employed and the total energy consumed. The decrease found in isokinetic activities was greater, and according to the author, they are the best recommended to patients with glaucoma. The author used in this study an equipment called dynamometer Cibex 6000, employed to measure efforts in different experimental situations. Thus, the outcomes obtained in Avunduk's study have great internal validity, but one cannot say the same concerning their external validity when compared to the current research. It is a real situation of physical exercise that, in its turn, has damaged. internal validity.

The current study does not inform on IOP variations during physical exercise, that is, IOP measured at the moment of lifting the load. It is not concerned either with relating the causes of IOP variations, nor with their relationships with the Valsalva maneuver, for it is a descriptive study. It deals with important information, once already mentioned articles showed significant variations of IOP during the Valsalva maneuver. Studies dealing with this subject are already being performed by the author.

CONCLUSION

This study showed that IOP significantly decreases after supine weight lifting exercise, performing isotonic work at eight repetitions in a group of young healthy subjects.

\section{ACKNOWLEDGMENTS:}

To the professors from the postgraduation course of the Universidade de Brasília, especially, Profs. David Duarte, Carlos Thomaz, Carlos Gonçalves, Liana Ferreira e Íris Ferrari.

To Brig. Médico José R. Gabriel e Cel. Médico Olavo Muller and to all volunteers and collaborators from the HFAB.

To the Professors and colleagues: Vital P. Costa, Regina Santos, Procópio Santos e Avni Murat Avunduk.

To Dr. Robert Ritch

\section{RESUMO}

Objetivo: Estudar as variações da pressão intra-ocular (Po) após o levantamento de peso na posição supina, em voluntários saudáveis. Métodos: Um estudo descritivo foi desenhado. Trinta e quatro voluntários foram pré-selecionados e 25 preencheram os critérios de inclusão para a fase final desta pesquisa. Aos voluntários, sadios, não portadores de glaucoma, foi solicitado que se levantasse peso na posição supina, com $85 \%$ da carga máxima, em série de 8 repetições. A Po foi aferida antes e após o esforço. Os resultados foram analisados pelo teste $t$ de Student. Resultados: houve pequena, mas significante diminuição da Po de 1,61 mmHg após a exposição dos 25 indivíduos (49 olhos) ao esforço físico específico. Conclusões: após o esforço físico de levantamento de peso em posição supina, e $85 \%$ da carga máxima, em 8 repetições, ocorre pequena, mas significativa redução da Po.

Descritores: Pressão intra-ocular/etiologia; Levantamento de peso; Esportes 


\section{REFERENCES}

1. Avunduk AM, Yilmaz B, Sahin N, Kapicioglu Z, Dayanir V. The comparison of intraocular pressure reductions after isometric and isokinetic exercises in normal individuals. Ophthalmologica 1999;213:290-4.

2. Lempert P, Cooper KH, Culver JF, Tredici TJ. The effect of exercise on intraocular pressure. Am J Ophthalmol 1967;63:1673-6.

3. Dolan J, Kacere RD, Squires RW, Brubaker RF. Effects of exercise conditioning on aqueous humor flow. J Glaucoma 1993;2:21-4.

4. Leighton DA. Effect of walking on the ocular tension in open angle glaucoma. Br J Ophthalmol 1972;56:126-30.

5. Kielar RA, Teraslinna P, Rowe DG, Jackson J. Standardized aerobic and anaerobic exercise: differential effects on intraocular tension, blood $\mathrm{pH}$, and lactate. Invest Ophthalmol 1975;14:782-5.

6. Ashkenazi I, Melamed S, Blumenthal M. The effect of continous strenuous exercise on intraocular pressure. Invest Ophthalmol Vis Sci 1992;33:2874-7.

7. Harris A, Malinovsky VE, Cantor LB, Henderson PA, Martin BJ. Isocapnia blocks exercise-induced reductions in ocular tension. Invest Ophthalmol Vis Sci 1992;33:2229-32.

8. Biró I, Botar F. Ueber das Verhalten den Augendrucks bei verschiedenen Sportsleistungen [abstract]. Kli Mbl Augenheilkd 1967;140:123.

9. Marcus DF, Edelhauser HF, Maksud MG, Wiley RL. Effects of a sustained muscular contraction on human intraocular pressure. Clin Sci Mol Med 1974;47:249-57.
10. Dos Santos MG, Makk S, Berghold A, Eckhardt M, Haas A. Intraocular pressure difference in Goldmann applanation tonometry versus Perkins handheld applanation tonometry in overweight patients. Ophthalmology 1998;105: 2260-3.

11. Dunn JS, Brubaker RF. Perkins applanation tonometer. Clinical and laboratory evaluation. Arch Ophthtalmol 1973;89:149-51.

12. Moses RA, Liu CH. Repeated applanation tonometry. Am J Ophthalmol 1968;66:89-91.

13. Stocker FW. On changes in intraocular pressure after application of the tonometer. Trans Am Ophthalmol Soc 1956;54:6.

14. Shencker HI, Luntz MH, Kels B, Podos SM. Exercise-induced increase of intraocular pressure in the pigmentary dispersion syndrome. Am J Ophthalmol 1980;89:598-600.

15. Brody S, Erb C, Veit R, Rau H. Intraocular pressure changes: the inffluence of psychological stress and the Valsalva maneuver. Biol Psychol. 1999;51: 43-57.

16. Erb C, Brody S, Rau, H. Effect of mental and physical stress on intraocular pressure - a pilot study. Klin Monatsbl Augenheilkd 1998;212:270-4.

17. Lanigan LP, Clark CV, Hill DW. Intraocular pressure responses to systemic autonomic stimulation. Eye 1989;3:477-83.

18. Rafuse PE, Mills DW, Hooper PL, Chang TS, Wolf R. Effects of Valsalva's manoeuvre on intraocular pressure. Can J Ophthalmol 1994;29:73-6.

19. Rosen DA, Johnston VC. Ocular pressure patterns in the Valsalva maneuver. Arch Ophthalmol 1959;62:810.

20. Harris A, Malinovsky V, Martin B. Correlates of acute exercise-induced ocular hypotenhsion. Invest Ophthalmol Vis Sci 1994;35:3852-7.

\title{
I Simpósio Básico e Avançado de Doenças da Retina e Coroide: da Teoria à Prática
}

\section{1 de outubro a $1^{\circ}$ de novembro de 2.
Hospital Offalmológico de Sorocaba SOROCABA - SP}

\author{
Coordenador: Arnaldo F. Bordon
}

INFORMAÇÕES: Tels.: (15) 212-9077 c/ Srta. Aline

E-mail: ceo@hosbos.com.br 